\author{
Andrzej Klimek \\ Research and Innovation Centre Pro-Akademia \\ ul. Innowacyjna 9/11, 95-050 Konstantynów Łódzki, Poland, andrzejrklimek@gmail.com \\ Isidoros Ziogou, Apostolos Michopoulos, Theodoros Zachariadis \\ Energy and Environmental Economics and Policy Group (3EP), Department of Environmental Science and \\ Technology, Cyprus University of Technology \\ Athinon and Anexartisias Corner, P.O. Box 50329, 3603 Lemesos, Cyprus, michopoulos.apostolos@ucy.ac.cy \\ Sadiq Gulma \\ Green Habitat Initiative \\ Abuja, Nigeria, sagulma101@gmail.com \\ Dina Suhanova \\ Faculty of Architecture and Design, „RISEBA” University of Business, Arts and Technology \\ Durbes iela 4, Riga, Latvia, dina.suhanova@riseba.Iv \\ Mure Agbonlahor \\ Agricultural Economics \& Farm Management Department, Federal University of Agriculture, \\ PMB 2240, Abeokuta, Ogun State, Nigeria, agbonlahormu@funaab.edu.ng \\ Sabine Jung-Waclik \\ Brimatech Services GmbH \\ Lothringerstraße 14/3, A-1030 Vienna, Austria, sjw@brimatech.at
}

\title{
GREEN ROOFS DISSEMINATION REGARDING THEIR POTENTIAL CONTRIBUTION IN ADDRESSING THE UHI EFFECT
}

\begin{abstract}
The article aims at summarising the state of the art in the efforts of researchers and innovators to find viable solutions to mitigate the urban heat island (UHI) effect. This effect is loosely connected with the greenhouse effect, however, it certainly creates a severe negative synergy together with it. As green roofs are a well-known answer how to address the UHI effect, the ways how to make their massive and global deployment convenient are discussed. Initially, the differences and similarities between urbanisation in developed and developing countries are described. Then the paper depicts solutions, especially synergic ones, for making the dissemination of green roofs viable, such as rainwater and energy harvesting or urban agriculture. Then the authors conclude that retrofitting the existing roofs is the only method for reaching the desired scale and discuss available business models necessary for introducing the prosumer approach to the retrofitting.
\end{abstract}

\section{Key words}

green roofs, Urban Heat Islands, urban regeneration, prosumer model, efficiency of FWE resources

\section{Introduction}

As the world's population approaches the 8 billion mark, a characteristic feature of the demographics, across countries, is the increasing rate of urbanization. The growth in the population of urban settlers cuts across countries and continents. Economic and social factors present strong pull factors that attract people, especially the youth and people within the economic age brackets, to urban areas. A cursory look at the growth trend over the last 3 decades suggests a sustained and rapid increase. It is estimated that over $65 \%$ of the world's population will be residing in urban areas by 2025. [1] In 2005 half of the global population lived in urban agglomeration areas. Worldwide, 457 large cities (with a population of 1,000,000 or more), 1,063 medium cities (with a population between 500,000 and $1,000,000$ ) and 2,896 smaller cities (population of more than 150,000) exist. [2] 
In 1810, so even before the global warming began, it was observed that the temperature of urban environment is higher than in the surrounding areas, nowadays for approximately $3^{\circ} \mathrm{C}$. [3] Then the reason of this phenomenon has been found in modifying the urban land surface (e.g. paving the roads or building houses), together with waste heating streams, and it has been called an urban heat island (UHI) effect. Its major consequence are the increasing: air conditioning demand, air pollution, greenhouse gas emissions, as well as the number of heat-related illnesses, including fatal ones. [4] It has also a negative impact on water quality. [3] Disturbed air circulation causes breezes at its perimeter while the centre remains still, which leads to an intensified steam condensation. This in turn results in more frequent rains. [5] In most of contemporary cities the rainwater is perceived as a problem rather than a resource. Furthermore, as rainwater passes by "concrete deserts", it is so hot that it can be dangerous for ecosystems of the surface water. [6] Additionally, all these phenomena cause a rain shadow effect at peri-urban areas, which should negatively affect the surrounding agriculture. [5] Furthermore, the hot air forms many kilometres-high stacks called urban thermal plumes. Their impact at higher latitudes, namely above $40^{\circ} \mathrm{N}$ and $40^{\circ} \mathrm{S}$, is much greater as net cooling in the Earthatmosphere system occurs there due to radiation. [7] It concerns especially highly urbanised areas of Northern Hemisphere. Nghiem et al. [8] claim that the plumes perturb the wind directions even in macroscale and the northern polar jet stream deviation leads to melting of the Arctic ice cap even more than the global warming. $\mathrm{UHI}$ effect reduction is a contribution not only to sustainability, but also to comfort of living in a given city. Summer heatwaves are fault of increased mortality of elderly people as within the United States alone, an average of 1,000 people die each year due to this reason, even though they affect only citizens living in temperate climate. [4] The number as well as the intensity of urban heat days (days with a maximum temperature over $30^{\circ} \mathrm{C}$ ) will dramatically increase in upcoming years (9.6 heat days average occurred yearly in Vienna between 1961 and 1990, while between 1981 and 2010 it raised to 15.2 heat days per annum mean). [9]

It is estimated that the heat accumulation in roofs is responsible in $40 \%$ of the average entire UHI effect impact. [10] The rise of the greenhouse gases emissions has been leading to warming the mean global temperature for $0.85^{\circ} \mathrm{C}$ between years 1880 and 2012 [11] and the ecological footprint is 1.6 times bigger than Earth's surface, which means that the global nature resources are depleted 1.6 times faster than they are renewed. [12] Therefore, lowering the accumulation and addressing the accompanying phenomena are an important challenge for the cities of the future. Without any adaptive urban design, the temperature greenhouse gas-induced increase until 2100 in California was calculated to be as high as 1.31 degrees Celsius, but a $100 \%$ deployment of "cool roofs" - meaning either green roofs, either traditional roofs diffusing much of solar radiation received, due to their bright colour - would result in a temperature drop of 1.47 degrees Celsius - more than the increase. [13]

The green roofs are the most common solution which has a potential of mitigating UHIs nowadays and improving the sustainability of the cities, even if such a single structure has only very limited impact on the environment and although in many cases they are not designed with such intention and they address the discussed problem only as a side effect of their presence. Firstly, the reflection coefficient for a green roof is hard to be measured, even though it is estimated that absorption of such a roof is 2 to 9 times lower than for an ordinary, dark roof structure. Secondly, green roofs have good thermal insulation properties, decreasing power demands for air-conditioning and space heating. Thirdly, their biological activity contributes to absorption of carbon dioxide and other greenhouse gases. Fourthly, they increase the water retention, mitigating this way a risk of a sudden local flooding, which rising frequency is another consequence of climate change. Last but not least, they provide heavily trafficked city centres with a green cover, which directly decreases the air pollution in those areas, most vulnerable to this phenomenon. All of these facts make the issues of green roofs dissemination and sustainable urbanisation strongly intertwined. The problems and challenges related to green roof construction and maintenance have been expanded in upcoming sections.

If we assume that tackling the UHIs by means of a mass-scale green roof introduction is a question of utmost importance, we remain failing to know who should take the responsibility of that. The developed countries are wealthy and globally indebted in terms of carbon emissions, while the developing countries are very populous, which means that potentially even a moderate increase of consumption level there, which seems to be inevitable eventually, would result in a big raise of carbon emissions. 


\section{Green roofs and urbanization in developed countries}

As previously stated by Georgescu et al., massive deployment of "cool roofs" would result in a significant temperature drop. [13] Still, this research was not related to the influence of green roofs, which would apparently have a greater positive environmental impact. Developed countries tend to be conscious of the climate change threats and opportunities to tackle them, like one mentioned above, meanwhile having powerful tools to introduce adequate policies. On balance, their responsibility for the climate change mitigation should be bigger, because biocapacity deficit of such countries as USA (-4.8 global hectares per person) [14] or Japan (-4.1 gha/person) [14] significantly contributes to making the whole world the ecologically indebted.

Therefore, developed countries are making research and implementation activities concerning the dissemination of green roofs and the former show it will be profitable. The simulations, assuming coverage of $50 \%$ of existing Southern California rooftops with green roofs or cool roofs, were made and demonstrated that it would give 1,625 GWh of direct energy savings per year, which would let save more than \$200 million and avoid producing 465 thousand tons of $\mathrm{CO}_{2}$ per annum. [15]

Planning regulations in many developed countries strongly encourage using green roofs, but predominantly in relation to new constructions. In Toronto, they are mandatory for the roofs with gross floor area of 2,000 $\mathrm{m}^{2}$ or higher. [16] The same in Copenhagen, where since 2010 they have been mandated in most new local plans. [17] Financial incentives have also been put into practice. The city of Vienna started a programme of financial incentives for constructions of new green roofs. The amount of funding depends on the substrate height $(\mathrm{cm})$ of the green roof system. It can range between 8 and $25 €$ per square meter, with an upper limit of 2,200 Euro per project. [18] Other European cities with subsidies for green roofs are Linz, Groningen, Rotterdam, Amsterdam and The Hague. [19]

Despite such an amount of evidence advocating green roofs dissemination and in spite of existing regulations discouraging from creating "dark roofs" on new buildings, the occurrence of green ones is still far from having a significant impact on climate, to any extent. Two main reasons for this are following: they are virtually absent in buildings from $20^{\text {th }}$ century or older, which still compose vast majority of the world's building stock, and even now they are still up to two times more expensive than regular structures, therefore the give no clear benefits for the investors $[20,21]$.

\section{Urbanization in developing countries}

Urbanization in developing countries is different from that of developed countries. [22] In the former, it is more associated with increase in natural population (excess birth rate over death rate), while in developed countries, it is more towards increased infrastructural and economic development with less increase in population.

In 2010, human population in developing and developed countries are estimated around 2.6 billion and 960 million with urbanization level of about $46 \%$ and $78 \%$ respectively. And this trend is expected to continue with over $90 \%$ of the population growth expected to take place in urban areas of developing countries. [22] Urbanization level of developing countries forecasted for the year 2050 is at $64.11 \%$ and the corresponding average annual rate of change of the percentage for urban areas between 2010 to 2050 is $1.70 \%$. The rate is more alarming when compared to that of developed countries for the same period which is $0.41 \%$. [22]

Another important factor accelerating urbanization in developing countries is migration from rural to urban areas, due to perceived better urban life and economic opportunities in cities. That is why Cobbinnah et al. described urbanization in Africa as premature often associated with unsustainable land development and huge urban poverty. [22] It is rapid, unplanned and unsustainable.

According to World Urbanization Prospects 2018, up to 68\% of the population in urban areas are projected to be living in slum conditions by the year 2050. [23] These shanty town conditions have been defined by UN HABITAT to be any of inadequate access to both sufficient water and sanitation, proper shelter to protect from adverse weather conditions, living in a room of not more than 3 people and prevention from forced eviction. [24] 
Cohen further identified other key challenges like socioeconomic fragmentation amongst cities (middle and high income areas enjoy better urban basic services than low income areas in the same city): water, waste management, land development planning and congestion. [25]

\section{Green roof dissemination in developing countries}

Much has not been recorded on direct green roof dissemination in majority of developing countries. Dissemination is mostly carried out through a general concept of promoting green building technologies (GBTs) or through the enforcement of green building regulations and rating systems. Using green roof dissemination largely limits substantive information to be found on the topic. However, using GBTs which encompasses green roofs may improve the situation on available data.

Some developing countries have green building rating systems they have adopted as a regulation. African countries continue to be the most interesting as part of those in developing world. Kenya and South Africa have set green building standards to follow as building regulations. They have adapted the Australian Green Start rating system to suit their local climate and needs. In Nigeria's capital city Abuja, developers are being asked to incorporate green building concepts when applying for building permits. However, these concepts are less specific about green roofs. A few countries though have considered possibilities of its usage through surveying building professionals.

Darko \& Chan reported on strategies needed to promote the adoption of GBTs and identified 5 top major things to do, as agreed by the responses of 43 construction professionals in Ghana to be statistically significant: increased publicity of GBTs in the media, related educational and training programs for professionals, making available institutional framework for effective implementation, strengthened R\&D (Research \& Development) and financial and further market based incentives for GBT adoption [26]. In comparison to US (a developed country) the strategies to promote dissemination and adoption differ, often because of economic status.

Chan et al. investigated the dissemination of green building technologies in Ghana, a developing country. The most critical barriers identified in their usage starts from the belief of high cost of employing GBTs, lack of government incentives, lack of financing schemes (e.g. Bank loans), unavailability of GBTs suppliers and lack of institutes and facilities for R\&D of GBTs, arranged in order of agreement by the respondents of the survey. [27]

Using a factor analysis of the 20 critical barriers identified from a literature survey, five groups emerged that categorized these barriers; government related, human related, information related, market related and cost and risk-related. The critical of them in Ghana is government related; lack of green building rating systems and labelling, lack of green building codes and regulations, lack of green building technological training for professionals, lack of GBTs promotion by government, lack of demonstration of projects, lack of local institutes and facilities for R\&D of GBTs and lack of government incentives. [27]

However, in Nigeria, a few of the government-related barriers are being reduced with the intervention of GIZ (Die Deutsche Gesellschaft für Internationale Zusammenarbeit GmbH - English: German Corporation for International Cooperation Ltd.) who works together with the Federal Ministry of Works. They have been able to develop an energy efficiency building code and put in place a training program for interested professionals.

Lotfi studied the green roof development in Iran [28] and reported similar results to Chan et al. [27] Cost of installing a green roof in Iran seems to be the biggest barrier to its adoption, followed by lack of managerial and policy aspects that failed to establish the critical role of green roofs in sustainably urban development.

Awareness on green roofs is not common to both among building owners and designers. Such concepts are more used by international clients who get contracts to build within the continent. Small and local contractors have little knowledge of green roofs promoted by the general lack of sufficient knowledge and research on the concept.

For green roofs to thrive, plants native to the areas must be known. Research on plants suitable to be used as green roofs is less with only a few reporting on the types of plant they used and success. 


\section{Energy \& water efficiency of green roofs}

Green roofs offer many positive services, among which are urban heat island (UHI) mitigation, increased thermal comfort for building occupants and important energy savings. [29] More specifically, heat fluxes from building roofs can decrease by roughly $80 \%$ in summer, while reduction in energy consumption during the same period can reach almost $17 \%$ compared with conventional roofs. A noteworthy temperature difference of the order of $4^{\circ} \mathrm{C}$ between traditional and vegetated roofs can also be spotted in winter. [30]

Various experimental approaches have been employed so far attempting to evaluate the thermal and energy performance of green roofs. Bevilacqua et al. found that under common Mediterranean climatic conditions and in comparison, with conventional roofing options, thermal energy entering from the building's green roof can be eliminated during summer, while the corresponding energy flowing outwards in winter can be reduced up to $37 \%$. [31] In Shanghai, a coastal city with hot and humid summers, the cooling effect of green roofs is more pronounced on sunny days, with the largest difference in heat flows through the roof reaching $15 \mathrm{~W} / \mathrm{m}^{2}$. [32] $\mathrm{ln}$ cold climates, like the one prevailing in West Lafayette, Indiana, the examined retrofit option was found to cut down the heat loss of the inner roof area by almost $18 \%$ during the whole heating period. [33] Green roofs also present higher air temperature above their surface compared to white gravel roofs in regions with temperate climates, where heating is more important than cooling. [34]

Recent studies have confirmed that the main factors influencing the energy efficiency of a green roof are the height of the selected vegetation, the leaf area index (LAI), the minimum stomatal resistance, and the growing medium's depth [35-37]. Berardi found that the examined building energy consumption is more strongly affected by soil height than by the LAl of the green roof, while the magnitude of LAl is proportional to the cooling effect on the local microclimate of urban areas. [38] This is of great importance, keeping in mind that the UHI effect is directly linked with energy consumption in cities - for example, the effect of the summer UHI alone has reportedly raised the air-conditioning load up to $12 \%$ in Manchester, UK. [39] Green roofs coupled with vegetation at pedestrian level positively affect the urban microclimate [40], with urban planning conditions, design configuration and prevailing local climatic characteristics being the major factors in their overall performance [41].

Apart from their contribution to energy conservation, green roofs are also beneficial for the management of storm water run-off in cities, where their implementation at a large scale can ultimately reduce urban flood events. [42-44] Percentage-wise, the water retention levels can range from $35.5 \%$ to $100 \%$, with a mean retention of $77.2 \%$ according to Zhang et al. [45] Moreover, a total average retention of $66 \%$ of a full-scale extensive green roof has been found by Nawaz et al. [46] In absolute terms and for optimal conditions, storm water storage capacities can vary from $25 \mathrm{~mm}$ to $40-50 \mathrm{~mm}$. [47]

In an effort to investigate the parameters affecting the water retention efficiency of green roofs, a stochastic weather generator coupled with a conceptual hydrological model have recently been used. [48] The results of this study indicated that the water retentiveness is proportional to the roof's soil depth, with humid subtropical climates being in favour of a green roof's retention performance and in contrast with Mediterranean ones. Following also a simulation approach, Szota et al. used a water balance model and found that the rainfall detention capacity can increase with the appropriate combination of irrigation regimes and drought tackling strategies. [49] Other parameters that play a determining role in the hydrological performance of green roofs are the vegetation characteristics and the physical properties of the layers' components. [50, 51]

The remaining water that escapes green roofs during intensive precipitation events can lead to leakage of nutrients and metals and thus may adversely affect the quality of downstream water bodies, especially in the case of recently applied constructions. [52] This can be mainly attributed to the high organic matter content of the green roof's soil substrate, which leads to a more brownish colour, dissolved salts and higher nutrient concentrations like phosphorous in the removed water. [53,54] According to Wang et al., adding an absorption layer comprising a mixture of active charcoal and/or pumice with perlite and vermiculite below the growing medium is sufficient to achieve the desirable balance between water runoff attenuation, pollution amelioration and optimal service lifetime of a green roof. [55] 


\section{Urban Agriculture and green roofs food production}

As it is estimated that over $65 \%$ of the world's population will be residing in urban areas by 2025 , this projection brings to fore issues of the sustainability of the system, because as cities expand, so do the food needs of urban families. [56] With increasing urbanisation, issue of sustainability of the food supply system have become more vexed with reference to social, economic, food production and environmental concerns. While alimentary and financial breakdowns are painful both for rural and urban dwellers, the urban poor have been suffering arguably the hardest considering food access, due to their low resilience. Consumers in the cities are almost exclusively dependent on buying food and changes in food prices and income have a direct translation into decreasing purchasing power and rising rates of food insecurity, thus affecting dietary quantity and quality this way. [57]

Meeting the food needs of the urban population in a sustainable manner is a major development challenge. Urban agriculture provides food, employment and incomes for urban dwellers [58-60]. The products are either consumed by the producers, or sold in urban markets, such as the increasingly popular weekend farmers' markets and organic kiosks found in many cities. The sustainability aspect of the production is emphasized because the locally produced food requires less transportation (pollution and cost) and refrigeration (packaging and storage), it can supply nearby markets with fresher produce.

Growth and expansion of urban agriculture over the years have been a result of high urban pull (both available and affordable) for food. The urban lifestyle and food demand regime are markedly different from those of rural societies. The difference in types of food demand can be attributed to the, characteristically, mobile and non-sedentary nature of urban employments, short family food preparation/consumption time, and increase in mass produced fast foods and highly variable income status. These characteristics orient the food needs to ready-to-eat or quickly prepared food items such as poultry, chips, fruits and vegetables. The need to supply these items not only cheaply but also freshly had encouraged urban and peri-urban agriculture. With increasing urbanization, the concern of how to furnish adequate amount of cheap, safe and nutritious food to the urban population has led to a reawakening of interest in urban agriculture.

Urban agriculture is a form of localising production (growing, processing, distribution and consumption) of food within the urban space. [61] Apart from the food security gains which entail the supply of cheap and fresh foods to the urban inhabitants, urban agriculture also adds environmental benefits and aesthetic appeal to urban environment. However, over time, the land space which was traditionally used for agriculture within the urban space has decreased or even ceased to exist due to increase in residential, commercial structures and facilities networks. In urban areas, due to the high demand of land for development and residential purposes, the opportunity cost of using land space for agricultural production is very high. Rooftop agricultural production or use of living roofs for food production had offered a new frontier in urban agriculture. While urban farming includes the production of crops and livestock, green roof or rooftop agriculture is most often associated with crop production. Osmundson succinctly set forth what typifies green roof agriculture, as the cultivation of crops in open space that is separated from the ground by a building or other raised structure. [62]

Rooftop agriculture is most exclusively used with crop production and the crops cultivated are usually annuals or short duration crops (fruits and vegetables). They are above-ground-level food production systems, involving use of raised platforms (spaces on top of human-made structures), referred to as green roofs or living roofs. Since they are above ground and usually on raised platforms, they present a separate set of operational challenges that have economic, architectural and biological implications. Some of the associated challenges that have been identified includes: high establishment and architectural re-engineering costs, limited space and load limits, accessibility, selection/choice of crops to be planted, as well as issues of pollution of roof runoff. However, some of the associated benefits from adopting green roof urban agriculture, apart from those mentioned before, include:

- Production of socially and economically cheap and fresh foods

- Retention (detain and slow runoff) of storm water which is a form of rain water harvesting technology. This has significant cost savings advantage in water cost reduction as well as in the design and management of infrastructure.

- Economically, they provide a durability effect on the roofing materials and insulate from sound and trap dusts. The green layer protects the roof membrane from harsh climatic effects, puncture, and UV damage. 
- The roof has full solar exposure with no risk of construction blocking the sun isolation. (minor risk of overshadowing by the neighbouring buildings)

- Aesthetic appeal associated with greening effects and the ability of the green roofs to attract and butterflies and birds to urban environments.

Asserting to the increasing popularity of green roof, Engelhard reported that green roofs are gaining popularity as a tool to mitigate many of the negative environmental effects caused by urbanisation. [63] He further highlighted that green roofs have been proven to reduce the UHI effect, absorb storm water, decrease energy used for heating and cooling, improve air quality, and sequester and store carbon and other greenhouse gases contributing to global climate change.

A study conducted by Ableman found that with good management conditions crops performance in green roofs approximate that under normal field condition as rooftop growing conditions are not substantially different from those on the ground. [64] Considering the fast urbanising rate of our cities and the concomitant demand for cheap, fresh and healthy foods, and with the identified economic, social and environmental benefits of using living roof for food production, it is envisaged that the future is bright for green roofs use in food production. In another study Engelhard made a study on the different types of design of living roofs. [65] While observing that rooftop agricultural projects are responding to poor environmental, social and economic conditions in cities, he highlighted global climate change, hunger and economic recession as among the issues shaping current urban gardens. He however concluded that though there are many encouraging signs for the growth of rooftop agriculture, issues of land tenure, natural resources, zoning, funding and development trends continue to affect their success.

\section{Optimizing food production efficiency from green roofs}

Efficiency in food production is attained when the output generated from the system exceeds the value of the technical inputs used. System efficiency is a precondition for sustainability. As an efficient food production system will support basic ingredients for a sustainable system, green roofs use in urban agriculture generates output that are cheaper in the long run. The availability of a ready and high-value consumer market in the urban area (farmers' markets, restaurants and organic kiosks) means that the products are exchanged for better prices and payment is usually direct to the producer. Also, there is usually little or no facilitating and logistic costs associated with transportation, storage and packaging. While limited space and the peculiarities of rooftop technology may limit the quantity and types of crops that can be produced from this system, the production system is highly efficient and factors productivity are high. Green roofs technology offers huge benefits to make modern food production cheaper and environmentally friendlier. [66]

Sustainable production system is a key element of the sustainable development goal (SDGs) of the United Nations. A sustainable system is one that incorporate the 3 pillars of profit, planet and people. It is a production system that yields a non-declining output over time while at the same time ensuring the natural resource base is not compromised. A sustainable urban food production system must therefore address issues of profitability and environmental sustainability. It will include the application of natural principles to grow enough food for people without depleting the natural resources that sustains it or polluting its environment and ensuring economic viability. According to Earles, variants of a sustainable agricultural system include organic, biodynamic, alternative and bio-intensive farming. [67] Sustainable agriculture is the product of a selfsustaining production intensification regime. It is an attempt to reduce over-exploitation of the natural resources base through the minimizing the depletion of native resources and use of external inputs in production. Sustainable agriculture was a response to green revolution that was characterized by industrial production models that emphasized high productivity at the expense of water, soil, biodiversity. [68] Soil, water, nutrients and biodiversity health are fundamental ingredients for a sustainable biological system. Sustainability is achievable by establishing cultivation practices that encourage the health of these elements. Key access benefits of rooftop gardens is their nearness and absence of competition from lack of tenure. An individual or business cultivating their roof space does not have to make the trip to and from an allotment or community garden. Also, one of the great insecurities of urban agriculture centres on tenure. Community gardens, allotments, and temporary garden plots are often displaced by what are viewed as more productive/developmental uses of the land. Lack of tenure has a profound effect on the activities undertaken in an agricultural enterprise. Most urban gardeners will be reluctant to invest the time and energy required if 
they cannot be assured continued use of the land. However, rooftop gardens are not likely to face competition with other uses of the space and can therefore offer greater security of tenure than other spaces. [69, 70]

\section{Retrofitting}

The world-famous Swiss-French modernist architect Le Corbusier advocated the use of the green roofs already in his architecture manifesto "Five points of Architecture" publicly announced in 1923. [71] Referring to him with the ongoing, still rising and above explained environmental concerns, nowadays it would be safe to say that use of the green roofs in the building construction is also a sustainably justified choice. The term "green roof", also called eco-roofs, living roofs, planted roofs or vegetated roofs, alludes to the roofs of the buildings that are partially or fully covered up with the living flora consisting of the strata of a waterproofing membrane, growing medium and the vegetation as a top layer. The roof can rightfully be called the fifth façade of the building, thus it is important to consider also such factors as the aesthetical look, the acquirements for its functional use and environmentally friendly performance, e.g. reduction of UHI effect, management and infiltration of the rainwater, air purification, improvement of the environment, reduction of $\mathrm{CO}_{2}$ emissions.

The application of the green roofs for new constructions nowadays is widespread globally. Although it may seem a contemporary trend with manifestation of roof gardens stretching back to modernist architecture, the history of the emergence of green roofs already dates back to the ancient times. The world's most famous green roof was one of the seven wonders of the ancient world - the hanging gardens of Babylon, constructed around $8^{\text {th }}-6^{\text {th }}$ century BCE. The green roof construction is also a tradition of hundreds of years in Scandinavia, especially Norway. For the vernacular building construction in Nordic countries the turf roofs soaked in the birch tar were used helping to cool the house in the summer and keep it warm in the winter. Scandinavian countries in general can be glorified for their experience and history in the use of green roofs.

The previous studies suggest that the use of green roofs is highly recommended in the refurbishment of already existing buildings. [15, 30, 38, 43, 65] Widely adopting the green roofs for building retrofitting may result in a number of local advantages, the increase of the building performance indicators as crucial one, essentially leading to the more global impacts described before. The building stock ages inevitably and the older buildings consume more energy comparing to the newly built, thus retrofitting by means of energyefficient technologies can leave significant impact. Typical flat roofs may be perceived also as aesthetically unattractive so speaking of the quality of urban life the green roof installed on the building can transform a lackluster rooftop into an aesthetically pleasing and attractive extra amenities for the occupants and humanize the built environment in the dense metropolis. As targeted in this research the green roofs can also serve for yielding crops and harvesting the food production. However, retrofit of the buildings with green roofs also comes with the certain challenges, namely structural restrains and additional loads, needs for the waterproofing and proper installation technology, access and maintenance.

There are two types of green roofs distinguished - extensive with the soil thickness between 5 and $15 \mathrm{~cm}$, where such plants as mosses, sedum, graminaceous and succulent are used, and intensive that is more similar to conventional roof garden with the growing variety of plants, shrubs, small trees and the soil thickness of more than $20 \mathrm{~cm}$. The difficulty of the retrofitting the buildings with green roofs lays in the fact that this kind of roof appends additional load on the existing roof structure. Taking into considerations the load-bearing capacity and weight considerations, the more suitable green roofs used for building retrofitting are the extensive ones - in Germany $80 \%$ of green roofs is extensive. [72] The reason for that is the comparably low added load, as the profile of the roof construction is lighter, thinner and may not require the additional support of the existing construction. Since the expected weight for extensive green roof is 50 to $200 \mathrm{~kg} / \mathrm{m}^{2}$, extensive and semi-intensive green roofs are more appropriate for retrofitting. The expected weight of typical turf roof is as much as $300-400 \mathrm{~kg} / \mathrm{m}^{2}$. [72] Choosing the plant species like stonecrop with lower requirements for the substrate, the weigh load of the roof can be diminished. As added weight may turn into expensive structural upgrade, it is crucial to keep the weight of the green roof lower, to consult with the structural engineer and use certain weight-saving strategies. The green roof can be applicable both to flat and steep constructions. If the steepness exceeds $20^{\circ}$, the substrate layer must be secured for the rinsing rainwater. [73] The steepness more than $40^{\circ}$ is not recommendable for the installation of the green roofs. As for the designers the following aspects should be also considered: the layout of the heaviest planted elements, drainage, safety measures for the maintenance and use, watering system for vegetation and the conditions of the site in general. The technical solution for the roof design may also differ in various climate zones. 
For the extensive green roofs popular in Europe, the layering consists of a coarse, mineral based growing medium, planted with sedum or other plants able to survive tough conditions. The typical composition of extensive green roofs are as follows: load-bearing slab or roof deck, vapor control barrier, insulation layer, waterproof membrane, root barrier (geo-textile), drainage layer, filter layer, growing substrate or porous soil and vegetation layer. Aforementioned small plants used for the top layer are selected so that they grow mostly horizontally ensuring dense coverage. The substrate is a rather thin layer of porous soil - mixture of sand, clay, mineral aggregates and organic substances. The thickness of the soil can be from 3 to $15 \mathrm{~cm}$. However the layer of soil for intensive green roofs to grow larger crops and trees may reach $60 \mathrm{~cm}$, the shrubs can be planted with $40 \mathrm{~cm}$ of soil, thus the weight of the green roof layering can reach $800-1000 \mathrm{~kg} / \mathrm{m}^{2}$. [73] In many cases the load-bearing capacity and the condition of the existing roofing system can limit the application of the green roof.

Building reconstruction and retrofitting to adjust the energy parameters of the building performance is widely performed but the studies confirm that the use of green roofs in building retrofit can be beneficial in several aspects: the prolongation of the life-cycle of the original roof construction, improving the building's energy efficiency, acoustic comfort, more natural look and feel, biodiversity, accessible public and private green area, urban gardening. However, still educating different actors, including designers and contractors and professionals specializing in green roof construction design is necessary. Admittedly, it's not always possible to convince developers to the application of green roofs, because there are still few examples in Northern latitudes and more conservative investors are not familiar with the technological advancements.

If we talk about a green roof, then, objectively, its construction is more expensive than a traditional, "dark" roof. Green roof solution will be more interesting for developers and owners with the concerns about sustainability and energy efficiency of a building. Independent researchers have shown that the green roof is a forward-looking and well-founded investment for both the private developer and the cities. This is also evidenced by the fact that more and more cities and countries are prohibiting flat roofs from new buildings and the installation of green roofs in many places is a mandatory requirement for them.

\section{Business models}

Nature-based solutions (NBS) are a form of eco-innovations. They promote nature as a means for e.g. providing solutions to climate change, low air quality, loss of biodiversity etc. and consist of different ecological domains, where buildings, facades and roofs are one of them. NBS can help overcoming urban sustainability challenges by providing services, creating benefits and holding value for different urban actors. The concept of business model innovation is a potential enabler of nature-based solutions and sustainability. Sustainable business model literature assesses the ability of certain business models to contribute to sustainability development and links environmental, social and economic performance of businesses to their technological, organizational and social innovation activities. [74] Bocken et al. propose 8 sustainable business model archetypes: [75]

- Maximize material and energy efficiency

- Create value from waste

- Substitute the use of finite resources with renewable and natural processes

- Deliver functionality rather than ownership

- Adopt a stewardship role

- Encourage sufficiency

- Re-purpose the business for society and environment

- Develop scale-up solutions

- NBS in the ecological domain of roofs are related to several sustainable business model archetypes:

- Maximizing material and energy efficiency: green roofs provide isolation and protection of buildings and their roofs

- Creating value from waste: building-integrated agriculture uses the water, heat and organic waste of the building which can be reused as input for delivering agricultural produce

- Substitute with renewable and natural processes: contribution to decreasing rain- and stormwater run-off, improving air quality through natural processes. [74]

These ecosystem benefits are of public nature, which leads to difficulties in finding private investments. For NBS related to a building, the investment decision takes place primarily at a decentralized level, with the building owner or the entrepreneur implementing the green roofs. [74] Khare et al. suggest a tripartite model, 
according to which initiatives must be financially beneficial to all stakeholders. [76] Collaboration between local government, local businesses and residents is a necessary condition and success depends on creating a balanced win-win situation for all stakeholders.

\section{Conclusions/Summary}

The contribution of the heat accumulated by the roofs to the urban heat island phenomenon is so vast that in theory the termination of this accumulation would be enough to reverse the entire phenomenon [13]. Even though, even in such environmentally conscious countries as the members of EU, the mass-scale introduction of green roofs is not easy and encounters many obstacles. One of the reasons is the fact that relatively much of urban tissue covering European cities is at least 50 years old, which means that it comes from the ages when environmental issues were hardly recognised and methods of retrofitting the existing green roofs have not been very developed yet. In the meantime, the cities in the developing countries are growing really fast, but this rise is uncontrolled and unsustainable. [22]

Further comparison between conditions in developed and developing countries did not give clear answer to a dilemma which of them should become a focus area for a green roof mass-scale introduction. In terms of the water retentiveness the green roofs in humid subtropical climates are better than in Mediterranean ones [48] and we can assume that the former ones represent the developing world, while the latter - the developed one. On the other hand, green roof retrofitting makes significant savings on heating, which is redundant in subtropical climates. $[31,34]$ It means that none of the areas of the globe is a natural leader which could be responsible for mass-scale introduction of such roofs.

Assuming that tackling the UHIs is priceless in terms of a climate change, a way to disseminate green roofs must be found, as otherwise there is no major chance that they become in widespread use unless they are simply profitable and in a foreseeable future no financial support from public authorities can be expected in the developing countries. Such incentives for green roof constructions can be found in some of the developed countries, but green roof conversions are more necessary instead, even though they are more expensive. To alleviate this discrepancy, extensive green roofs are recommended.

All of this means that the world needs solutions that would make new green roof constructions in developing countries and of green roof retrofitting in developed countries profitable and the prosumer model is a good prospect for such an option. It is based on an assumption that is a cornerstone for the dispersed renewable energy production idea, which implies that energy, in a form of electricity, heat or gas, but also other consumable utility goods, like water or food, can be not only consumed, but also produced almost effortlessly by the users of a building, in this specific case covered by green roof.

Especially merging the idea of urban farming with green roofs looks promising, as the urban growing conditions they have many economic advantages that have been mentioned while not being substantially different from those on the ground. It is also a little contribution to the sustainability, as agricultural land use, among natural ones, is one of the least carbon footprint reducing. Still, in terms of economic costs, the extensive green roofs seem to be better than intensive ones.

\section{References}

[1] United Nations, Department of Economic and Social Affairs, Population Division, World Urbanization Prospects: The 2014 Revision, Highlights (ST/ESA/SER.A/352). https://esa.un.org/unpd/wup/publications/files/wup2014-report.pdf Retrieved 06. 07. 2018

[2] A. Mazlan, Between Vision and Reality of Becoming a Smart City, 3rd Smart Cities Conference, Kuala Lumpur 2017 http://www.smartcitiesasia.com/smart-city-vision/ Retrieved 06. 07. 2018

[3] Heat Island Effect, Environmental Protection Agency, https://www.epa.gov/heat-islands Retrieved 06. 07. 2018 
[4] S.A. Changnon Jr., K.E. Kunkel, B.C. Reinke, Impacts and responses to the 1995 heat wave: A call to action, Bulletin of the American Meteorological Society. 77 (1996), 1497-1506. doi:10.1175/15200477(1996)077<1497:IARTTH>2.0.CO;2

[5] C.C. van Heerwaarden, J. Vilà-Guerau de Arellano, Relative humidity as an indicator for cloud formation over heterogeneous land surfaces", Journal of the Atmospheric Sciences. 65 (2008), 3263-3277.

[6] E. Shochat, P.S. Warren, S.H. Faeth, N.E. Mclntyre, D. Hope, From Patterns to Emerging Processes in Mechanistic Urban Ecology, Trends in Ecology \& Evolution. 21 (2006) 3. doi:10.1016/j.tree.2005.11.019.

[7] J.E. Walsh, W.L. Chapman, V. Romanovsky, J.H. Christensen, M. Stendel, Global Climate Model Performance over Alaska and Greenland, J. Climate. 21 (23) (2008), 6156-74. doi:10.1175/2008JCLI2163.1.

[8] S.V. Nghiem, I.G. Rigor, D.K. Perovich, P. Clemente-Colón, J.W. Weatherly, G. Neumann, Rapid reduction of Arctic perennial sea ice, Geophysical Research Letters. 34 (2007) L19504

[9] L. Wiesboeck et al., Heat Vulnerability, Poverty and Health Inequalities in Urban Migrant Communities: A Pilot Study from Vienna, in: W. Leal Filho, U.M. Azeiteiro, F. Alves (Eds.), Climate Change and Health: Improving Resilience and Reducing Risks, Springer, Berlin, 2016, p. 392.

[10] R.A.W. Albers, P.R. Bosch, B. Blocken, A.A.J.F. Van Den Dobbelsteen, L.W.A. Van Hove, T.J.M. Spit et al., Overview of challenges and achievements in the Climate Adaptation of Cities and in the Climate Proof Cities program, Building and environment. 83 (2015) 1-10.

[11] Climate Change 2013: The Physical Science Basis, IPCC Fifth Assessment Report, WGI AR5 (2013) 5.

[12] Global Footprint Network, Data Sources, http://data.footprintnetwork.org/ Retrieved 06. 07. 2018

[13] M. Georgescu, P.E. Morefield, B.G. Bierwagen, C.P. Weaver, Urban Adaptation Can Roll Back Warming of Emerging Megapolitan Regions, Proceedings of the National Academy of Sciences of the United States of America. 111 (2014) 2909-2914. doi:10.1073/pnas.1322280111

[14] National Footprint Accounts edition (Data Year 2014); building on World Development Indicators, The World Bank (2016); U.N. Food and Agriculture Organization, Rome, 2018.

[15] N. Garrison, C. Horowitz, C.A. Lunghino, How Green Roofs and Cool Roofs Can Reduce Energy Use, Address Climate Change, and Protect Water Resources in Southern California, Natural Resources Defense Council \& Emmett Center on Climate Change and the Environment at UCLA School of Law, Report 12-06-B, Los Angeles, 2012.

[16] City of Toronto, Green Roof Bylaw https://www.toronto.ca/city-government/planningdevelopment/official-plan-guidelines/green-roofs/green-roof-bylaw/ Retrieved 06. 07. 2018

[17] Green Roofs Copenhagen, http://www.klimatilpasning.dk/media/631048/green_roofs_copenhagen.pdf Retrieved 06. 07. 2018

[18] International Green Roof City Network. Case Study Vienna, Austria, http://www.igraworld.com/images/city_network/IGRN-Case-Study-Vienna-IGRA.pdf Retrieved 06. 07. 2018

[19] G. Prokop, H. Jobstmann, A. Schonbauer, Overview of best practices for limiting soil sealing or mitigating its effects in EU-27, European Commission, Final report, Brussels, 2011.

[20] T. Carter, A. Keeler, Life-cycle cost-benefit analysis of extensive vegetated roof systems, Journal of environmental management. 87.3 (2008) 350-363. 
[21] I. Ziogou, A. Michopoulos, V. Voulgari, Th. Zachariadis, Energy, environmental and economic assessment of electricity savings from the operation of green roofs in urban office buildings of a warm Mediterranean region, Journal of Cleaner Production. 168 (2017) 346-356.

[22] P.B. Cobbinah, M.O. Erdiaw-Kwasie, P. Amoateng, Africa's urbanization: implications for sustainable development, Cities. 47 (2015) 62-67.

[23] United Nations Department of Economic and Social Affairs (UN DESA). 2018 Revision of World Urbanization Prospects. https://www.un.org/development/desa/publications/2018-revision-of-worldurbanization-prospects.html, Retrieved 06. 07. 2018

[24] UN HABITAT. State of the World's Cities 2006/07. http://mirror.unhabitat.org/documents/media_centre/sowcr2006/SOWCR\%205.pdf Retrieved 06. 07. 2018

[25] B. Cohen, Urbanization in developing countries: Current trends and future projections, and key challenges for sustainability, Technology in Society. 28 (2006) 63-80.

[26] A.P.C. Chan, A. Darko, Strategies to promote green building technologies adoption in developing countries: The case of Ghana. Building and Environment, 130 (2018) 74-84.

[27] A.P.C. Chan, A. Darko, A.O. Olanipekun, E.E. Ameyaw, Critical barriers to green building technologies adoption in developing countries: the case of Ghana. Journal of Cleaner Production, 172 (2018) 1067-1079.

[28] S. Lotfi, An investigation of urban green roof development in developing countries (a case study of Iran), Advances in Civil, Environmental, and Materials Research (ACEM' 12), http://www.iasem.org/publication_conf/acem12/W4F-7.pdf, Retrieved 06. 07. 2018

[29] O. Saadatian, K. Sopian, E. Salleh, C.H. Lim, S. Riffat, E. Saadatian et al., A review of energy aspects of green roofs, Renew Sustain Energy Rev. 23 (2013) 155-168. doi:10.1016/j.rser.2013.02.022.

[30] A.B. Besir, E. Cuce, Green roofs and facades: A comprehensive review, Renew Sustain Energy Rev. 82 (2018) 915-939. doi:10.1016/j.rser.2017.09.106.

[31] P. Bevilacqua, D. Mazzeo, R. Bruno, N. Arcuri, Experimental investigation of the thermal performances of an extensive green roof in the Mediterranean area, Energy Build. 122 (2016) 63-69. doi:10.1016/j.enbuild.2016.03.062.

[32] Y. He, H. Yu, N. Dong, H. Ye, Thermal and energy performance assessment of extensive green roof in summer: A case study of a lightweight building in Shanghai, Energy Build. 127 (2016) 762-773. doi:10.1016/j.enbuild.2016.06.016.

[33] X. Tang, M. Qu, Phase change and thermal performance analysis for green roofs in cold climates, Energy Build. 121 (2016) 165-175. doi:10.1016/j.enbuild.2016.03.069.

[34] M. Taleghani, M. Tenpierik, A. van den Dobbelsteen, D.J. Sailor, Heat mitigation strategies in winter and summer: Field measurements in temperate climates, Build Environ. 81 (2014) 309-319. doi:10.1016/j.buildenv.2014.07.010.

[35] A.H. Refahi, H. Talkhabi, Investigating the effective factors on the reduction of energy consumption in residential buildings with green roofs, Renew Energy. 80 (2015) 595-603. doi:10.1016/j.renene.2015.02.030.

[36] C.M. Silva, M.G. Gomes, M. Silva, Green roofs energy performance in Mediterranean climate, Energy Build. 116 (2016) 318-325. doi:10.1016/j.enbuild.2016.01.012.

[37] V. Costanzo, G. Evola, L. Marletta, Energy savings in buildings or UHI mitigation? Comparison between green roofs and cool roofs, Energy Build. 114 (2016) 247-255. doi:10.1016/j.enbuild.2015.04.053. 
[38] U. Berardi, The outdoor microclimate benefits and energy saving resulting from green roofs retrofits, Energy Build. 121 (2016) 217-229. doi:10.1016/j.enbuild.2016.03.021.

[39] C.P. Skelhorn, G. Levermore, S.J. Lindley, Impacts on cooling energy consumption due to the UHI and vegetation changes in Manchester, UK, Energy Build. 122 (2016) 150-159. doi:10.1016/j.enbuild.2016.01.035.

[40] S.S. Alcazar, F. Olivieri, J. Neila, Green roofs: Experimental and analytical study of its potential for urban microclimate regulation in Mediterranean-continental climates, Urban Clim. 17 (2016) 304-317. doi:10.1016/j.uclim.2016.02.004.

[41] T.E. Morakinyo, K.W.D. Kalani, C. Dahanayake, E. Ng, C.L. Chow, Temperature and cooling demand reduction by green-roof types in different climates and urban densities: A co-simulation parametric study, Energy Build. 145 (2017) 226-237. doi:10.1016/j.enbuild.2017.03.066.

[42] S.S.G. Hashemi, H. Bin Mahmud, M.A. Ashraf, Performance of green roofs with respect to water quality and reduction of energy consumption in tropics: A review, Renew Sustain Energy Rev. 52 (2015) 669-679. doi:10.1016/j.rser.2015.07.163.

[43] M. Karteris, I. Theodoridou, G. Mallinis, E. Tsiros, A. Karteris, Towards a green sustainable strategy for Mediterranean cities: Assessing the benefits of large-scale green roofs implementation in Thessaloniki, Northern Greece, using environmental modelling, GIS and very high spatial resolution remote sensing data, Renew Sustain Energy Rev. 58 (2016) 510-525. doi:10.1016/j.rser.2015.11.098.

[44] A. Volder, B. Dvorak, Event size, substrate water content and vegetation affect storm water retention efficiency of an un-irrigated extensive green roof system in Central Texas, Sustain Cities Soc. 10 (2014) 59-64. doi:10.1016/j.scs.2013.05.005.

[45] Q. Zhang, L. Miao, X. Wang, D. Liu, L. Zhu, B. Zhou et al., The capacity of greening roof to reduce stormwater runoff and pollution, Landsc Urban Plan. $144 \quad$ (2015) 142-150. doi:10.1016/j.landurbplan.2015.08.017.

[46] R. Nawaz, A. McDonald, S. Postoyko, Hydrological performance of a full-scale extensive green roof located in a temperate climate, Ecol Eng. 82 (2015) 66-80. doi:10.1016/j.ecoleng.2014.11.061.

[47] B.G. Johannessen, H.M. Hanslin, T.M. Muthanna, Green roof performance potential in cold and wet regions. Ecol Eng. 106 (2017) 436-447. doi:10.1016/j.ecoleng.2017.06.011.

[48] F. Viola, M. Hellies, R. Deidda, Retention performance of green roofs in representative climates worldwide, J Hydrol. 553 (2017) 763-772. doi:10.1016/j.jhydrol.2017.08.033.

[49] C. Szota, C. Farrell, N.S.G. Williams, S.K. Arndt, T.D. Fletcher, Drought-avoiding plants with low water use can achieve high rainfall retention without jeopardising survival on green roofs, Sci Total Environ. 603-604: 2017;340-51. doi:10.1016/j.scitotenv.2017.06.061.

[50] S.S. Cipolla, M. Maglionico, I. Stojkov, A long-term hydrological modelling of an extensive green roof by means of SWMM, Ecol Eng. 95 (2016) 876-887. doi:10.1016/j.ecoleng.2016.07.009.

[51] C. Szota, T.D. Fletcher, C. Desbois, J.P. Rayner, N.S.G. Williams, C. Farrell, Laboratory tests of substrate physical properties may not represent the retention capacity of green roof substrates in situ, Water (Switzerland). 9 (2017) doi:10.3390/w9120920.

[52] I. Buffam, M.E. Mitchell, R.D. Durtsche, Environmental drivers of seasonal variation in green roof runoff water quality, Ecol Eng. 91 (2016) 506-514. doi:10.1016/j.ecoleng.2016.02.044.

[53] J. Hill, J. Drake, B. Sleep, Comparisons of extensive green roof media in Southern Ontario, Ecol Eng. 94 (2016) 418-426. doi:10.1016/j.ecoleng.2016.05.045. 
[54] S. Beecham, M. Razzaghmanesh, Water quality and quantity investigation of green roofs in a dry climate, Water Res. 70 (2015) 370-384. doi:10.1016/j.watres.2014.12.015.

[55] X. Wang, Y .Tian, X. Zhao, The influence of dual-substrate-layer extensive green roofs on rainwater runoff quantity and quality, Sci Total Environ. 592 (2017) 465-476. doi:10.1016/j.scitotenv.2017.03.124.

[56] U.N. Food and Agriculture Organization in collaboration with U.N. Centre for Human Settlements (Habitat), Feeding the cities: The role of urban agriculture - factsheet, FAO, Rome, 1999.

[57] U.N. Food and Agriculture Organization, Fighting poverty and hunger: What role for Urban agriculture. http://www.fao.org/docrep/012/al377e/al377e00.pdf Retrieved 06. 07. 2018

[58] L.J.A. Mougeot, Growing better cities: Urban agriculture for sustainable development, International Development Research Centre, Ottawa, 2006.

[59] M. Hendrickson, M. Porth, Urban Agriculture-Best Practices and Possibilities, University of Missouri Extension, St. Louis, MO, 2012.

[60] C.G. Shabbir, J. Smit, A. Ratta, J. Nasr, Urban Agriculture: Food, Jobs and Sustainable Cities, United Nations Development Programme, New York, NY, 1996.

[61] M.U. Agbonlahor, S. Momoh, A.O. Dipeolu, Urban vegetable crop production and production efficiency, Int J Veg Sci. 13 (2007) 63-72. doi:10.1300/J512v13n02_06

[62] T. Osmundson, Roof gardens: history, design, and construction. Greenbacks from green roofs: forging a new industry in Canada, Canadian Mortgage and Housing Corporation, Ottawa, 1999.

[63] B. Engelhard, Rooftop to tabletop: Repurposing urban roofs for food production. An unpublished Master's Thesis in Landscape Architecture, University of Washington, Seattle, WA, 2010.

[64] M. Ableman, Agriculture's Next Frontier: How urban farms could feed the world, UTNE Reader. 102 (2000) 60-65.

[65] B. Engelhard, Green Roofs Will Flourish: Obstacles and Solutions in U.S. Green Roof Retrofits. Research paper for LARCH 561, University of Washington, Seattle, WA, 2008.

[66] L.L. Sheung, Rooftop Garden: Planting Seeds of Service, The Teacher's network, Boston, MA, 2001.

[67] R. Earles, Sustainable Agriculture: An Introduction, ATTRA: The National Sustainable Agriculture Information Service, Melbourne, Vic., 2005.

[68] G. Trauger, S. McFadden, Farms of Tomorrow Revisited: Community Supported Farms, Farm Supported Communities, Biodynamic Farming and Gardening Association, Kimberton, PA, 1997.

[69] J. $S^{t}$ Lawrence, Urban agriculture: the potential of rooftop gardening. An unpublished Master's Thesis in Environmental Studies, York University, Toronto, Ont., 1996.

[70] L.J. Pearson, L. Pearson, C.J. Pearson, Sustainable urban agriculture: Stocktake and opportunities, International Journal of Agricultural Sustainability. 8 (2010) 7-19.

[71] Le Corbusier, Five points of Architecture, in: Le Corbusier, Towards a New Architecture, J. Rodker, London, 1931. Reprint: Dover Publications, New York, 1985.

[72] E.C. Snodgrass, L. McIntyre, The Green Roof Manual: A Professional Guide to Design, Installation, and Maintenance, first ed., Timber Press, Portland, OR, 2010. 
[73] V. Bokalders, M. Bloka, Ekoloǵiskās būvniecības rokasgrāmata: kā projektēt veselīgas, racionālas un ilgtspējīgas ēkas, Domas spēks, Riga, 2013.

[74] H. Toxopeus, F. Polzin, Characterizing nature-based solutions from a business model and financing perspective. Deliverable 1.3 Part V of the H2020 project "Naturvation" https://naturvation.eu/sites/default/files/news/files/naturvation_characterizing_nature-

based_solutions_from_a_business_model_and_financing_perspective.pdf Retrieved 06. 07. 2018

[75] N.M.P. Bocken, S.W. Short, P. Rana, S. Evans, A literature and practice review to develop sustainable business model archetypes, Journal of Cleaner Production. $65 \quad$ (2014) 42-56. https://doi.org/10.1016/i.jclepro.2013.11.039

[76] A. Khare, Beckman, N. Crouse, Cities addressing climate change: Introducing a tripartite model for sustainable partnership. Sustainable Cities and Society. 1(4) (2011) 227-235. https://doi.org/10.1016/j.scs.2011.07.010 